\title{
Religious imaginations in embroidered craft art ${ }^{1}$
}

\section{Annekie Joubert}

Institut für Asien- und Afrikawissenschaften, Humboldt-Universität zu Berlin, Unter den Linden 6, D-10099, Berlin, Germany, and Department of Visual Arts, University of Pretoria, Pretoria 0002, South Africa

e-mail: jouberan@staff.hu-berlin.de

\begin{abstract}
This article focuses on 'religious spaces' that embroidered craft art denotes in a rural Northern Sotho community in South Africa, and the way in which spirituality is imagined through this form of art. Some background information on the craft artists of the Mogalakwena Craft Art Development Foundation (MCADF) in South Africa and the embroideries produced by them is given in the introduction. Examples of embroidered panels with religious and embedded cultural motives are then discussed. The focus of the discussion in the second part will be on (i) the influence of Christianity through Christian missions on indigenous African societies; (ii) the development of African Independent Churches in South Africa with special reference to the Zion Christian Church (ZCC) and (iii) an analysis of examples of the embroideries in order to understand the complex fusion of African religion and Christianity. This article finally suggests that the craft art embroideries of the Mogalakwena craft artists reflect a spirituality that is 'poised in transition', a spirituality that is 'linking backwards and forwards at the same time' allowing 'modernity to be represented in older cultural forms, while cloaking older forms of tradition in newer guises' (Venter, 2004:9).
\end{abstract}

\section{Introduction ${ }^{2}$}

The Mogalakwena Craft Art Development Foundation (MCADF) was founded in 1994 by $\mathrm{Dr}$ Elbé Coetsee. ${ }^{3}$ MCADF is situated between the Blouberg mountain and the Mogalakwena river in the remote northern part of the Limpopo Province in South Africa. The exclusive aim of the Foundation is to promote indigenous art and craft inherent in a Northern Sotho community, to restore the intrinsic craft skills of the people, and to enable more members of the community to become self-sufficient and less dependent on unemployment government grants. Today, more than 20 craft artists are employed on a full-time basis and another 10 on a part-time basis by the Foundation. During 2000, the Foundation started to concentrate on the documentation of the innumerable aspects of Northern Sotho culture ${ }^{4}$ through the medium of embroidery. The embroidery, which is often referred to as 'story cloths' in craft art literature, covers a wide range of imagery related to everyday subject matter within the local communities. The focus of this article will be on the pictorial embroideries of the MCADF as 'religious space of expression', and their use of 'visual language' or iconic signs in the postulation and transmission of African spirituality.

For centuries, the Sesotho sa Leboa-speaking ${ }^{5}$ people of South Africa lived a rural life with no written language, but with many traditions that were passed on orally by word of mouth. The vast majority of the craft artists at MCADF is still illiterate and did not attend school at all, and only a small number completed primary school. The embroideries are produced in a communal manner through the communal memory of artists, pertaining to culturally specific events, such as marriage, childrearing and traditional homemaking, to rituals and rites of passage, such as cleansing rituals, religion, healing, burial, initiation and performance and song. The craft artists use the 'multiple language' of iconic and arbitrary signs as their mode of communication. They stage live events in silent visual forms - providing them with ekphrasis ${ }^{6}$ (words or cryptic annotations) in order to give, directly or indirectly, 'voice' to the embroidered pictures. The written texts are embroidered on an adjacent cloth, making it part of the final craft art product. These visual creations are imitations of spiritual events and discourses known to the craft artists.

It should be pointed out at this point that the addition of ekphrasis to the embroideries was only a later development, one that could be explained in terms of the high level of illiteracy among the craft artists, on the one hand, and ascribed to the surrender to Western culture on the other, where the power of visual representation has always been limited '... through an exegetical and, indeed, ekphrastic tradition which translates the pictorial into the readable, thus controlling and encircling it with words' (Wagner, 1996:31).

When the documentation process started in 2000, the artists did not include their names or dates on the panels, a true reflection of a communal participation process. However, since 2005, they have started to indicate names and a date. The names often reflect the person(s) who made the drawing and the person(s) who participated in the embroidering process or even the person(s) who was (were) responsible for the written text (ekphrasis).

The immanent synthesis of cultures and the interplay between tradition and modernity can be observed in the embroideries produced at MCADF - offering a fascinating glimpse into the emergence of African Christian popular culture in the aftermath of democratisation now displayed in an embroidered pictorial form. The craft art can be 
described as pictorial panels, representing the spiritual lives of villagers, where indigenous knowledge and tradition fuse with the aspiration of Christian conversion and modernity.

\section{Influence of Christianity on indigenous African societies through Christian missions ${ }^{7}$}

During their first encounters with Africans, Europeans who came from a Judeao-Christian tradition, had difficulties in understanding the religious codes of the indigenous African inhabitants. Missionaries diabolised indigenous religion by recasting local gods and spirits as Christian demons that operate under the auspices of Satan (Meyer, 2008:9596). Their disregard of the different forms of indigenous religion was based on the perceived absence of so-called 'understandable' languages, and the non-existence of Christian doctrines and practice in the lives of indigenous people. The initial denial and inauspicious visual presentation of indigenous African religion resonated wildness, bestiality, savagery and obviously a denial of any form of religion. ${ }^{8}$ This denial signifies in general terms a perception of 'otherness', and the re-conceptualisation of the 'un-known', allowing for the intervention in the lives of indigenous people, measured and perceived from 'outside', against a European form of Christianity, and conception of God; as well as a church culture that was marked by its 'Greco heritage and its presuppositions of Logos and ration' (Anderson, 2001:xii).

The importance for most missionaries who set out to bring the good news to the heathens in southern Africa was the total conversion of Africans to a European cultural and moral code. This move was interpreted as a religious sign of conversion, and the African's spiritual inclination towards Christianity. It becomes evident that Christianisation demanded enormous religious and cultural adjustments, not only on the part of the missionaries, but even more on the part of the indigenous people. The reason for this lies in the fact that the 'African social, religious, political and economic system was such an integrated whole that any attempt to change one dimension of the system unavoidably influenced all the other dimensions' (Saayman, 1991:31).

There developed, in the words of Krige and Krige (1943:326), ' '... a tendency among the best-educated Natives to revive the past in answer to the challenge of the European', because missionary influence stretched beyond the mere provision of a religious framework to the cultural transformation of the societies touched by their work. Christian mission therefore became part of colonial acculturation in southern Africa because of its imposition of Western culture. It is therefore not surprising that Christianity is often represented in African literature in an ambiguous manner: on the one hand as a vehicle of imperial colonial supremacy and the key agent in the rupture of Africans from their traditional culture, or on the other hand as the force of civilisation and Europeanisation (Gikandi, 2009:8).

\section{The development of African Independent Churches (AICs) ${ }^{9}$}

In this process of acculturation, the power and dominance of colonial rule left indigenous people with little choice but to change and to adapt to many of the dominant society's cultural traits. ${ }^{10}$ Western missionary activity in southern Africa became a potent force for all kinds of cultural and particularly religious change. Theology as such became alien to the faithful, causing an explosion of African religious codes into various new forms. The result was the emergence of African Independent Churches (AIC) where new African meanings were assigned to European Christian religious codes.

The revitalisation of religion from inside the indigenous communities can be seen as attempts by Africans to restore the breakdown in their societies in terms of feelings of helplessness and spiritual demoralisation to their former state of self-confidence and prosperity. Comaroff (1985:175-176) makes the case that the prophet-healing churches, like the Zionists, used their metaphor of healing as the reintegration of matter and spirit, the practical agency of divine force, and the social relocation of the displaced'. In Comaroff's (1985:175-176) view the AICs became a counterforce in transforming 'everything that had been set apart in the black experience of colonialization and wage labor'. This perpetuation of African culture in the second half of the 19th century gave impetus to the breakaway church movements in South Africa in order to restore identity and a sense of purpose. Venter (2004:25) constructed the following definition from the different viewpoints of scholars studying AICs:

An African Independent Church (AIC) is a grouping established for religious purposes associated with Christianity in Africa by Africans for Africans, which remains independent of groupings outside Africa for funding, leadership or control - even should it affiliate to bodies that include non-Africans. AICs may exhibit distinctively African social structures, symbols, rituals, practices, beliefs and liturgy.

The 2001 census estimated the number of church denominations of the AICs in South Africa to be 6000 , including 14.54 million people, a staggering $37.75 \%$ of all black South Africans, of which many were former members of the historic mission churches (Venter, 2004:28). The relentless growth of South African AICs can be attributed to their approval of, and promotion of traditional beliefs within their churches, and the bridge that the AICs form between rural-urban and African-Western continuums. Anderson (2001:x) views this revitalisation as a 'religious revolution, an African reformation' that has changed Christianity irrevocably.

The craft art panels to be discussed in this article represent one of the most prominent church groupings in the movement of AICs in southern Africa, namely the Zion Christian Church (ZCC).

\section{The Zion Christian Church (ZCC)}

The Zion Christian Church was founded by Engenas Lekganyane (c. 1880-1948) who was born in the Mamabolo area, currently known as the Limpopo Province, in South Africa. Lekganyane, who suffered from a serious eye disorder, first belonged to a Zionist congregation. According to ZCC tradition, he was praying on a mountain in 1910 
when he received a revelation that God would give him strength to found a large church. Elias Mahlangu, who founded the Zion Apostolic Church of South Africa (ZAC) in 1917 baptised Lekganyane, resulting in his healing (Anderson, 2001:98-99). Lekganyane was ordained in the ZAC and emerged as leader of his own congregation in Thabakgone, his home village. He became leader in the Limpopo Province in 1918 operating as a prophet who emphasised the idea of direct and personal revelation by the Spirit, earning him many converts. His legacy as a unique prophet grew even stronger after his prophesy of Germany's defeat by Britain in 1917 (Anderson, 2001:99). $\mathrm{He}$ finally cut his ties with the Zion Apostolic Church in 1920 when he moved to Lesotho to join Edward (Lion) Motaung's Zion Apostolic Faith Mission (ZAFM) as bishop of the former Transvaal. Differences between the two led to Lekganyane's return to Thabakgone in 1924 to establish his own church, the Zion Christian Church (ZCC). In 1930, Lekganyane was forced to leave his home village after a dispute with his local chief. His church members helped him to raise money to buy a farm in Boyne in close proximity of Polokwane, formerly known as Pietersburg. This farm was named Moria, and since then became the headquarters of the ZCC and a mecca for the Zionists' pilgrimage. With the official registration of the church in 1942 by the South African Government, it consisted of 55 congregations and 27487 members. A year later, the ZCC membership increased to more than 40000 (Anderson, 2001:100-101).

Lekganyane focused on divine healing, first by laying on hands and later through symbolic ritual practices such as the blessing of various objects, and the sprinkling of blessed water in protective and cleansing rituals. A prerequisite for protection is the prior confession of sins, without which the blessed medicine is ineffective (Anderson, 2001:101-102).

Engenas Lekganyane died in 1948, opening up a leadership struggle between his two sons: Edward, the eldest, and Joseph, the appointed heir. Edward contested Joseph's leadership on the grounds of the traditional Pedi custom that regards the eldest son as rightful successor to the father's position. This feud led to the formation of two separate churches in 1949. The minority faction followed Joseph, coining the name St Engenas Zion Christian Church and using a silver dove on a green flash as their badge. The majority followed Edward and maintained the original name Zion Christian Church, as founded by his father. They use the five-pointed silver star on a green flash as their badge. The headquarters of the two churches are located on adjacent farms at Moria, and little difference exists in terms of their beliefs and practices. Edward was considered a very effective leader with a huge following who sought to renew the ZCC into a more biblical direction in the 1960s. He died in October 1967 and was succeeded by his son Barnabas Ramarumo who was only 13 years old at the time. The church was governed by a superintendent until 1975 when Barnabas took over after his 21st birthday. Barnabas furthered his theological training through a Bible correspondence course at the All-Africa School of Theology of the veteran North American Pentecostal missionary, Fred Burke. The ZCC generally took a neutral stance towards politics, since its registration in 1925 .
Through all generations its bishops played a constructive role - unfailingly preaching racial harmony and reconciliation (Anderson, 2001:102-3).

The ZCC is characterised by their focus on divine and faith healing, and immersive baptism (Venter, 2004:19). The church upholds certain African customs such as purification rites, the use of holy water, the wearing of blessed cords or cloth, prophesying, night communion, river baptism and ritual dancing. ${ }^{11}$ It is further believed that the bishop (bišhopo), who also functions as the spiritual and executive leader of the church, acts as a mediator between the congregants and God through Jesus Christ, a resemblance with the tribal chief who is called Modimo wa lefase 'the god of the earth', and who is the one that intercedes with the Badimo ba godimo 'the gods of the above' (ancestors) for collective benefits. ${ }^{12}$

The two craft art panels to be discussed deal with the Zion Christian Church of Barnabas Ramarumo Lekganyane, using the five-pointed silver star as their badge.

\section{Craft art as 'religious space' in the proclamation of African spirituality ${ }^{13}$}

The Mogalakwena craft art panels, like other pictures or words, operate merely as representations of something, and every craft art panel is a construction of meaning by the artist(s) who made it (Heffernan, 2002:36). The difference, however, between pictures and words according to Heffernan (2002:36), is 'that words are arbitrary and pictures natural, that words represent things by convention alone while pictures represent them by natural resemblance'.

The craft art panels do not give us unmediated access to what they represent. As 'viewers/readers' we need to interpret them as semiotic signs and cultural constructions of meaning, and in order to 'see/read' the panels accurately, we must be acquainted with the culture and spirituality that these panels represent. As Meyer (2008:97) explains 'images are not convincing by themselves, but work in the context of particular grammars and traditions of usage which induce particular dispositions and practices toward them'. Yet, most 'viewers/readers' are able to recognise, to a certain extent, what the panels represent without full knowledge of the cultural background that frame them, a pictorial competency that seems to be inborn. According to Gombrich (as quoted by Heffernan, 2002:44), the effect of resemblance or the illusion of reality that we get from pictures, is "created by visual clues corresponding to the bits of information we seek from natural objects in order to know what they are'. He maintains further that the images in a painting are 'not replicas of natural objects but signals that must be decoded before their meaning as representations can be understood' (Gombrich in Heffernan, 2002:44). In the same way we cannot 'see/read' the craft art panels by 'instinct' alone. Heffernan (2002:45) warns that 'representation as such requires a consciousness of the difference between painted objects and real ones, between signifier and signified'. Our two-dimensional pictorial panels are therefore pictures of depiction - pictures of the way in which spirituality is commonly understood and represented by the Mogalakwena craft artists. These craft art panels can be 


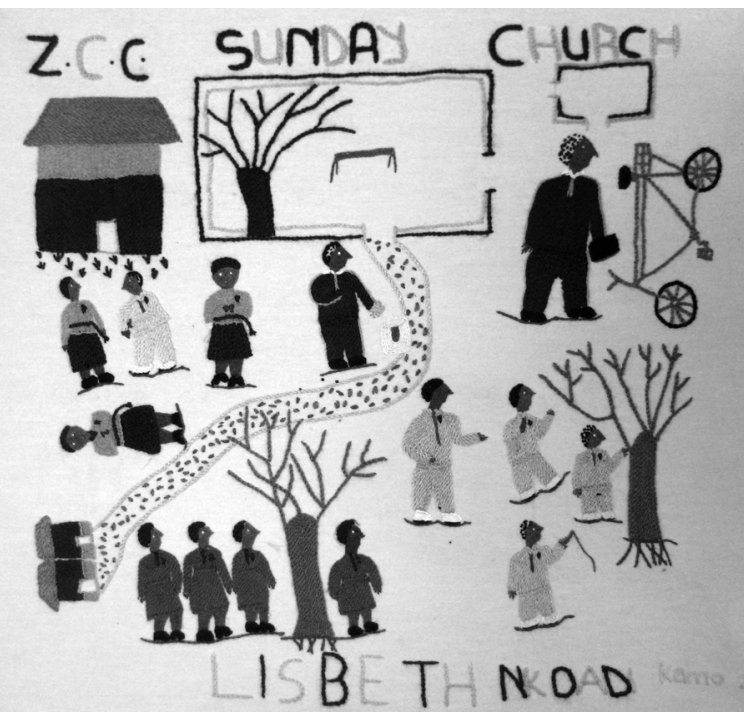

Figure 1: Panel 1(a): ZCC Sunday Church

regarded as representational art, embedded in an inseparable totality of cultural specificity, variability and emergence - demanding decoding. ${ }^{14}$ They 'show/tell', in pictorial terms, the lives and spirituality of the community. The scenes represented in the art demand the decoding of their richly embroidered rhetoric fabric where the 'viewer/reader' is urged to make sense of the iconic signs of pictures as well as the arbitrary signs of language simultaneously (Wagner, 1996:16). In my 'viewing/reading' I will heed Heffernan's (2002:35) warning 'that we cannot "recognize" the meaning of pictures unless and until we are willing to interpret their signs, which largely depend on the cultural contexts and conventions within which they are framed'.

The following part of this article offers a brief analysis and interpretation of the religious craft art panels produced by the Mogalakwena artists, seeking to understand the specificity of each panel as an entry-point into the imagined religious spaces depicted in the panels and the cross-fertilisation between indigenous and contemporary Christian religion in this community.

\section{Examples of South African Independent Christianity ${ }^{15}$}

\section{Zion Christian Churches}

Panels 1(a) and 1(b) (Figures 1 and 2, respectively) were embroidered by Lisbeth Nkoadi in 2005 on a white cotton background. The embroidered headlines in capital letters and in the colours of the ZCC on the pictorial panel differ from those on the accompanying Sesotho sa Leboa ekphrasis. The themes dealt with in both panels are clearly indicated. When reading the ekphrasis, the identity of the church denomination is revealed as being that of the ZCC, depicting senior officials or ministers (baruti $)^{16}$ at work, assisting a sick or troubled woman:

Ba swere modiro wa dithapedišo Tempeleng. Mo gareng ga bona gona (sic) le mosadi yo a tlemilwego maoto le matsogo. Baruti ba gare ba mofa (sic) kalafi ya maleba gore a boele maemong a gagwe a mabotse.

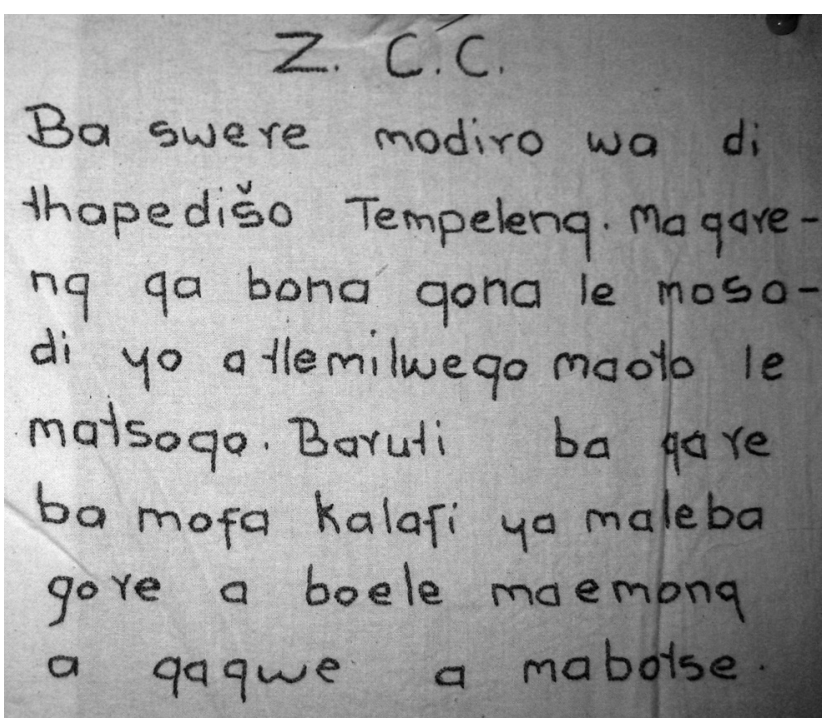

Figure 2: Panel 1(b): Ekphrasis ZCC

'They are busy praying in the Temple. In the midst of them is a woman whose feet and hands are bound. The senior officials [ministers] in the middle are treating her in order for her to return to her normal self.' (Own translation)

Panel 1 represents the faction of Barnabas Lekganyane, the church that has the star as its badge. Although this panel is produced in a rural village approximately $150 \mathrm{~km}$ from the ZCC headquarters of Moria, its layout and proxemic markers resemble that of Moria. As I discussed the panel with the interlocutors, it became clear that they merge the representation on cloth with its referent. The work of art becomes an embodiment of the real place with a spiritual presence evoking a sense of the sublime in the viewer, especially these craft artists and interlocutors who are also ZCC members (Meyer, 2008:85, 87).

We see, at the bottom left side, two welcoming gates (Figure 1). All visitors and congregants are usually inspected at these gates by the so-called 'church police' (maphodisa a kereke), consisting of men and women. Women are not allowed to wear pants or tights under their dresses. They have to cover their heads and arms, and are not allowed to wear blouses with low neck lines. After passing the 'gate test' congregants are allowed to gather at the central enclosure (kgorong), where trees are visible, to socialise (phaphatela). At this quarter, the congregants would commonly dance and sing, and drink specially blessed tea and coffee as well as holy water (mogabolo).

As church members enter the welcoming gates for the 'gate test', prophets (maporofeta), who can determine the presence of any kind of evil, await the congregants before they enter the church enclosure. It is believed that God (Modimo) 'dresses' or 'covers' (apeša) the prophets with the Holy Spirit through the help of angels (mangeloi). ${ }^{17}$ The prophets then lead the troubled congregants along the footpath (as indicated on the panel in Figure 1) to private demarcated areas (mašakeng). ${ }^{18}$ The dots on the footpath signify all the identified congregants on their 


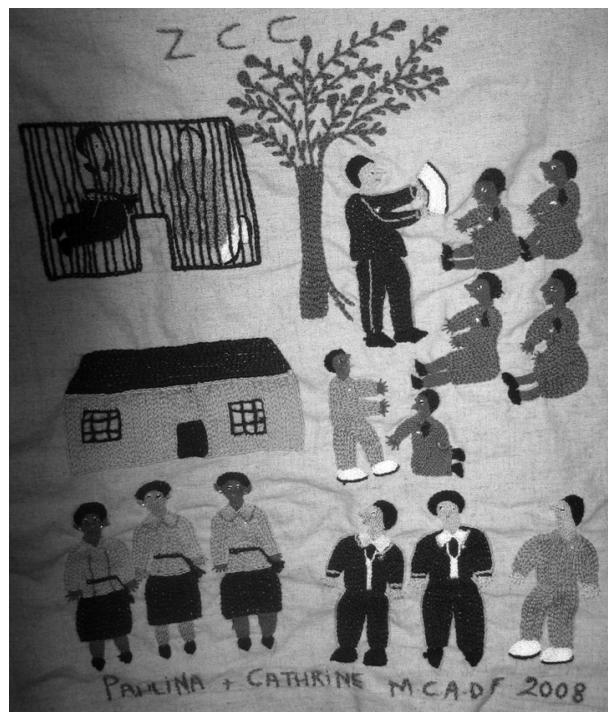

Figure 3: Panel 2(a): ZCC

way to the demarcated areas. Once they have arrived at the demarcated area the prophets will, together with an interpreter (mohlatholli), give each troubled congregant revelations (dikutollo) and instructions (ditaelo) regarding his or her current problems, misfortunes, illnesses and future - clearly indicating the church's closeness to its members' reality of local gods and spirits. Everything is written down by the interpreter on a piece of paper, after which the paper is then given to the troubled congregant with some instructions to follow. The prophet will also instruct a congregant on self protection mechanisms to be used against evil, for example what to eat and drink, what to avoid, what to wear and how to strengthen one's power. One such a mechanism is the wearing of white cords which consist of strings of cloth (metlamo) worn around certain parts of the body. It is believed that these cords protect a person against evil, an object retained from the realm of traditional religion. These cords are usually worn under one's clothes in order not to be visible and susceptible to witchcraft. The cords can be bought in bundles of ten, at the cost of R6 at the headquarters Moria close to Polokwane. ${ }^{19}$

Anderson (2001:196) explains that in African religions, life and existence is inextricably tied up with power, and a person's living power lies in the ability to strengthen or weaken another person's power directly or by the manipulation of the power of non-human things. Prophets in the ZCC have taken over the function of traditional healers. Healing and purification symbols take a central position in church life and show 'direct parallels with traditional healing methods' (Anderson, 2001:197).

The building in the top left corner (Figure 1) represents one of many shops at Moria where church clothes and special protective objects and products are manufactured and sold. These products include blessed water, special tea produced for healing purposes labeled as the 'tea of life', brown maize flour, walking sticks blessed by the bishop, and protection cords. The sprinkling of 'blessed water' plays a significant role in the methods of healing employed by the ZCC. As in traditional practices, blessed

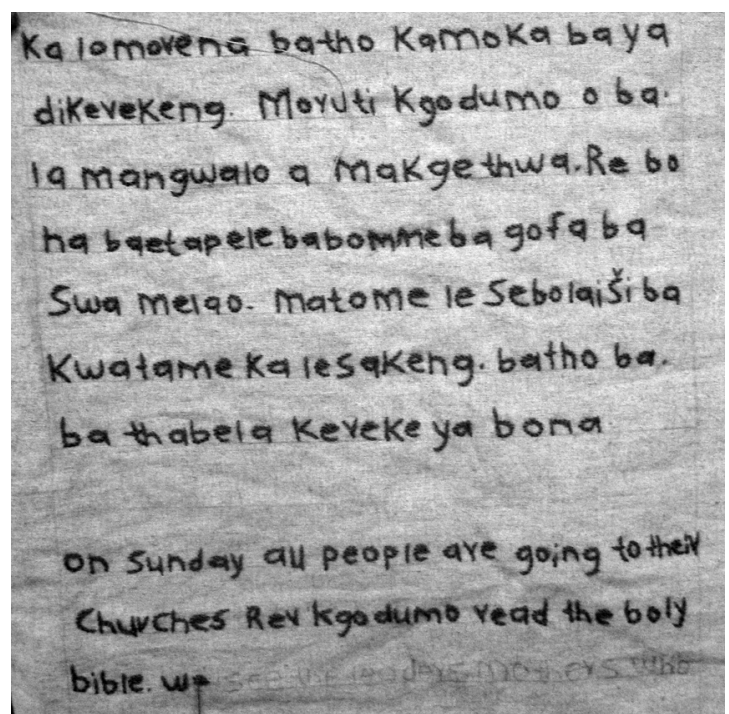

Figure 4: Panel 2(b): Ekphrasis

water is used to purify people and objects; to protect people against evil such as sorcery, witchcraft and misfortune, or to sanctify congregants in their daily endeavours as regards job opportunities, the passing of examinations or health matters. ${ }^{20}$

Baptism (kolobetšo) takes place on a daily basis at Moria. The people that are ready to be baptised are led by ministers (baruti) and followed by other congregants to the river Kwenane, located at the headquarters. Men are baptised first. The minister baptises a person by saying: 'I baptise you in the name of the Father, the Son and the Holy Spirit' (Ke go kolobetša ka leina la Ntate, le la Morwa Ntate le la Moyamokgethwa) during which time a person's head is submerged three times. The minister will then bless the baptised person. After the baptism ceremony, the newly baptised put on dry clothes and receive a badge from one of the attendants. Instructions on the laws of the church are then given to the newly baptised by the older and more experienced women in the church (bomme ba bagolo). The newly baptised join the older women in singing. They all return to the church enclosure where they receive their baptism cards (karata ya kolobetšo). ${ }^{21}$

Panels 2(a) and 2(b) (Figures 3 and 4, respectively) also represent the denomination of the ZCC that uses the star as badge.

Panels 2(a) and 2(b) (Figures 3 and 4) were embroidered by Paulina and Cathrine in 2008. The pictorial panel appears on a brownish cotton background while the Sesotho sa Leboa ekphrasis appears on a white cotton background. An embroidered headline ZCC in capital letters only appears on the pictorial panel (Figure 3). The absence of a headline on the accompanying ekphrasis might be ascribed to the fact that the artists were still working on it at the time of my research. The accompanying ekphrasis not only supplies the viewer/reader with a specific time when the event took place, but also names the characters by name, and explains their roles and activities:

Ka lamorena [sic] batho kaMoka [sic] ba ya 
dikerekeng. Moruti Kgodumo o bala mangwalo a makgethwa. Re bona baetapelebabomme [sic] ba gofa [sic] bafswa melao. Matome le Sebolaiši ba kwatame ka lesakeng [sic]. batho [sic] ba ba thabela kereke ya bona.

'On Sundays all the people attend church. Minister Kgodumo reads scriptures from the Holy Bible. We see the leaders of the women giving instructions to the new ones. Matome and Sebolaiši are kneeling in the kraal [demarcated place]. These people rejoice in their church.' (Own translation)]

As written in the ekphrasis, the pictorial panel in Figure 3 represents a scene from a Sunday church gathering. The panel simultaneously depicts the various groups that have been formed within the ZCC to provide prayer and communion encounters for members. The first group to be discussed are the matured women (bomme ba bagolo), who appear in the bottom left corner. These women are usually a bit older, have already children and live exemplary lives in their communities. They are dressed in a special way called seaparo se segolo the dress of the matured ones'. The dress cannot be bought at random, but has to be 'earned' through one's deeds, and only after confirmation has been given by the ministers. The women then 'graduate' (go godišwa) in order to give them power to look after the younger women. The outfit costs approximately $€ 70$ (R700) and is available at the headquarters of Moria. It consists of a yellow long sleeve shirt (hempe) with a green sash (moogo/meogo), a green skirt (sekhethe) and a green head scarf (tuku). They are allowed to wear any black shoe as long as it is a closed shoe. The women usually wear these outfits on Wednesdays which are regarded as prayer days and Sundays at church. The Wednesday gatherings start at 14:00 and end at 17:00. Women are allowed to read from the Bible, to sing religious songs called the hymns of Zion (difela tša Sione), and to pray. They often receive instructions (ditaelo) from prophets to pray for certain members in the congregation. A male minister oversees the women's proceedings at all times and is regarded as the 'herder of the sheep' (mohlokomedi wa dinku). The gathering is always closed with prayer by a male minister in order to receive the grace of God on behalf of the women (go re tšeela mohau). ${ }^{22}$

The second group includes five seated women that appear in the right hand corner (Figure 3). They represent the younger women (basadi ba bafsa), and are referred to as the female choir. They are dressed in blue long sleeve shirts and matching blue skirts. These outfits are called leratadima, meaning 'the blue of heaven'. The outfits are rounded off with green berets (mengatse) and black shoes. They cost approximately $€ 60$ (R600). As these women are younger it is believed that they have adequate power and energy to dance and sing. They usually practice on Saturdays and Sundays from 12:00 until 14:00.

In the middle of the scene appear two men in khaki outfits (Figure 3). This third group is called Mokhukhu, meaning 'shack' or 'shanty', and is generally regarded as the most important of all the groups because of their powerful and energetic dance performance. Their outfits consist of a jacket, long trousers, white shoes (manyanyatha) and black hats (dikepisi) with a star pinned on the front.

Women can also wear a khaki outfit that consists of a khaki long sleeve shirt and a skirt, costing $€ 40$ (R400). These outfits are only worn at funerals, Saturday choir gatherings and when they dance the mphoho wa selala 'whole night dances'. The mphoho dances could be compared to the traditional malopo or trance dances. Choir members receive instructions (ditaelo) from a prophet that the mphoho should be performed at a certain household. The dance then starts at midnight on Saturday and continues until 04:30 on Sunday morning. The dancers then disperse to their homes to refresh and to change into their green and yellow outfits. They return later to the house where the dancing took place and continue dancing until 14:00 when the Sunday church service starts.

The fourth group (Figure 3) represents the ministers (baruti) or matured men. These men are dressed in green striped jackets and pants called 'the dress for matured men' (seaparo se segolo sa banna). The outfits are rounded off with a white shirt, green tie, black hat and black shoes and cost $€ 100$ (R1 000). The wearing of the ZCC badge is obligatory when one wears any of the above outfits. Ministers fulfil an important role in the structures of the ZCC since they organise and lead Sunday church services and assist congregants in personal praying. A person cannot pray directly to God, but has to follow a certain procedure. One firstly has to approach one's own ancestors through the help of angels (mangoloi). When that is done, one asks the minister (moruti) who in his turn approaches his own ancestors in order to request permission to pray to God via the bishop of the ZCC.

Church services do not take place in a building, but in the open. Various ministers assist one another in conducting a church service. Every Sunday, ministers are chosen for that particular service. Men and women use separate entrances to the place of worship and are also seated in a specific order. The first minister opens the service with a prayer and asks the congregation to kneel down and pray together softly. The minister will then explain the procedure of the service and make some announcements, for example if there are people to be baptised. The second minister reads from the Bible. The reading will be closed with the singing of songs (dikoša) and hymns of Zion (difela tša Sione). The third and fourth ministers will follow the same procedure as the second. The fifth minister, who is usually the head of that specific congregation, will preach, lead the congregation in singing, and close the service with a prayer. The choir will actively participate in the proceedings. Holy Communion is not celebrated in the ZCC.

\section{Conclusion}

World Christianity has moved from the North Atlantic to the South, with southern Africa as its new heartland. According to Pobee (cited in Anderson, 2001:ix), Christianity on the African continent grew from 29 million people in 1983 to 54 million people in the year 2000. Pobee (in Anderson, 2001:ix) ascribes this enormous growth not only to protest movements against the so-called historic Churches, but also to an African Reformation which deals with matters of 
epistemology and ontology 'the questioning, the hopes and fears of Homo Africanus'.

Through the religious imaginations portrayed in the craft art panels we could observe how effectively interaction between Christianity and African religion in the ZCC has taken place. The panels provide examples of how traditional cultural and religious observances have been modified and transformed to hold Christian meaning. This interaction and transformation led to indigenisation, contextualisation and the intercultural communication of the Christian gospel - conveying 'novel' social, cultural and ideological values through the visual dimensions of craft art. According to Anderson (2001:193-194) these issues are important to theology and the formation of an African theology that is relevant to the felt needs of millions of people, and a theology that counteracts the 'more rationalistic and inflexible Christianity brought by western missionaries'.

The strength of the ZCC church lies in its 'Africanness' - its creative response to re-building dignity and self-worth among African people, to let them feel 'at home' and to organise their position in the world. Many Africans join the ZCC today because its theology is manifested in holism through healing, where healing does not only refer to physical healing, but the ongoing process of finding wholeness in the totality of one's life. ${ }^{23}$ Members of the ZCC apply an African hermeneutical process to interpret and contextualise the Bible in their daily lives (Anderson, 2001:220). In this process, they do not only 'enlarge' the meaning of the Bible to include this Africanness, they also open African religion up to the modern world. This notion is in accordance with the observation made by Meyer (2008:83) that:

the anthropology of religion in Africa has shifted from a focus on distinctly African cultural symbolic repertoires that were conceptualized as 'authentically' African, toward a keen interest in the place and role of religion in the context of modernity and globalization.

\section{Notes}

1 The term 'craft art' as used in this article depicts handcrafted embroidered cloths with a strong aesthetic appeal that concurrently transmit social, cultural and ideological values. See Coetsee (2002:8-9) for a discussion on the notion 'craft art' in South Africa.

2 This article is a continuation of the research I started in 2008 at the Mogalakwena Craft Art Development Foundation on 'craft art as intermedial space of expression'. See Joubert (2009).

3 I would like to thank Dr Elbé Coetsee, for allowing me permission to do research on the craft art produced at the Mogalakwena Craft Art Development Foundation, and the Mogalakwena craft artists, for sharing religious issues with me, explaining their complexity and for assisting me with the interpretation of the pictorial panels discussed in this article. My sincere thanks also go to Sylvia Mabore and Magauwane Lebotse for sharing some thoughts on religion and personal experiences with me.

4 In this article the term 'culture' is understood as it is defined by Ember and Ember (1999:17), namely as 'the set of learned behaviours, beliefs, attitudes, values, and ideals that are characteristic of a particular society or population'. Also see their discussion on the defining features of culture (Ember \& Ember, 1999:17-19).
5 Sesotho sa Leboa, also commonly known by the geographical description 'Northern Sotho', is not a single, uniform language. It designates the geographical area within which a collection of dialects are spoken. These dialects include among others sePedi, seTlokwa and seBirwa and are spoken especially in the following provinces of South Africa: Limpopo, Mpumalanga, Gauteng, and the North-West. The official language, that is the language which is endorsed by the Language Board, and which is used in schools, official documents and the media, is based on one of the dialects of Sesotho sa Leboa, namely sePedi, and is often referred to as the standard form of Sesotho sa Leboa.

6 Scholars have defined and used the term ekphrasis in numerous ways, depending on the particular rationale to be employed. Heffernan (1991:299) defines ekphrasis as 'the verbal representation of graphic representation'.

7 See Joubert (2008). The Christianisation process among Sesotho sa Leboa-speaking communities in South Africa started in the mid-1900s with the arrival of German missionaries from the Berlin Mission Society. See Richter (1924).

8 The first artist who tackled this problem was Hans Burgkmair, the Elder of Augsburg who issued a broadsheet in 1508 of a couple identified as 'Hottentots'. This work reveals a reversed image of Dürer's 'Adam and Eve' of 1504. By switching or replacing cultural codes, Burgkmair makes use of a well-known Christian image, to assimilate the savage Khoikhoi to Adam and Eve, newly expelled from the Garden of Eden, but this time dressed in garments of skin by the Lord God to hide their nakedness (Genesis 3:31). The artist thereby imposed his familiar ideas and thoughts of Western religious codes on those of the Khoikhoi in order to familiarise his spectators with a foreign nomadic African society (Strother, 1999:4).

9 The terms 'African independent churches', 'African initiated churches', 'African instituted churches' and 'African Initiatives in Christianity' are terms that are recently used by scholars such as Anderson, Pobee and Ositelu to replace the outdated term 'African indigenous churches'.

10 See Barrett's (1968) 'Tribal Zeitgeist' theory as a central cause for the development of thousands of African independent churches (AICs) throughout the African continent.

11 Personal communication from Sylvia Mabore, Polokwane, March-April 2011 and Magauwane Lebotse, Pretoria, MarchApril 2011.

12 See Mönnig (1967:56).

13 See Joubert (2009).

14 See Panovsky (1982:28-31) for his theory on pictorial meaning, and the three layers of meaning: factual, conventional and symbolic meaning.

15 This discussion is based on Anderson (2001:98-113).

${ }^{16}$ Baruti is a noun in class 2 and can be translated with pastors, priests or ministers.

17 The Sesotho sa Leboa expression is Modimo o apeša moporofeta ka moya (personal communication by Magauwane Lebotse, Pretoria, September 2008.

${ }^{18}$ Mašaka is a noun in class 6 and can be translated with 'kraal' or enclosure.

19 Personal communication from Sylvia Mabore, Polokwane, March - April 2011.

20 Personal communication from Mokibelo Louisa Seabi, Selina Mabuša Phokela and Raisetša Elisa Ngoepe, Mogalakwena Craft Art Centre, September 2008.

${ }^{21}$ Personal communication from Sylvia Mabore, Polokwane, March - April 2011.

${ }^{22}$ Personal communication from Magauwane Lebotse, Pretoria, March - April 2011.

${ }^{23}$ Personal communication from Mokibelo Louisa Seabi, Selina Mabuša Phokela and Raisetša Elisa Ngoepe, Mogalakwena Craft Art Centre, September 2008. 


\section{References}

Anderson AH. 2001. African reformation: African initiated Christianity in the 20th century. Trenton: African World Press, Inc.

Barrett DB. 1968. Schism and renewal in Africa: An analysis of six thousand contemporary religious movements. Nairobi: Oxford University Press.

Coetsee E. 2002. Craft art in South Africa. Cape Town: Struik Publishers.

Comaroff J. 1985. Body of power, spirit of resistance: The culture and history of a South African people. Chicago and London: University of Chicago Press.

Ember CR, Ember M. 1999. Cultural anthropology. New Jersey: Prentice Hall.

Gikandi S. 2009. Christianity and Christian missions. In: Gikandi S (ed.), The Routledge encyclopedia of African literature. London: Routledge Taylor \& Francis Group. pp 108-112.

Heffernan JAW. 1991. Ekphrasis and representation. New Literary History 22:297-316.

Heffernan JAW. 2002. Literacy and picturacy: How do we learn to read pictures? In: Hedling E, Lagerroth $U$ (eds), Cultural functions of intermedial exploratio. New York: Rodopi. pp 35-66.

Joubert A. 2008. "I am a Morula tree on the border line": From ancestors to Christian prophets in Southern Africa. In: Machalík $\mathrm{T}$, Mildnerová K, Záhorík J (eds), Proceedings of the Third International Conference on African Studies. PIzen: ADELA Publishing. pp 12-25.
Joubert A. 2009. Memory embroidered: Craft art as intermedial space of expression. In: Gehrmann S, Prüschenk V (eds), Klang, Bild, Text. Intermedialität in afrikanischen Literaturen 17:97-126.

Krige EJ, Krige JD. 1943. The realm of a Rain-Queen. London: Oxford University Press.

Meyer B. 2008. Powerful pictures: Popular Christian aesthetics in Southern Ghana. Journal of the American Academy of Religion 76:82-110.

Mönnig HO. 1967. The Pedi. Pretoria: JL van Schaik Limited.

Panovsky E. 1982. Iconography and iconology: An introduction to the study of Renaissance art (1939). In: Panovsky E (ed.), Meaning in the visual arts. Chicago: University of Chicago Press. pp 28-31.

Richter DJ. 1924. Geschichte der Berliner Missionsgesellschaft 1824-1924. Berlin: Verlag der Buchhandlung der Berliner ev. Missionsgesellschaft.

Saayman W. 1991. Christian mission in South Africa. Pretoria: University of South Africa.

Strother ZS. 1999. Display of the body Hottentot. In: Linfors B (ed.), Africans on stage. Bloomington: Indiana University Press. pp 1-61.

Venter D. 2004. Engaging modernity. London: Westport, Connecticut.

Wagner P. 1996. Introduction: Ekphrasis, iconotexts, and intermediality - the state(s) of the art(s). In: Wagner $P$ (ed.), Icons - Texts - Iconotexts: Essays on ekphrasis and intermediality. Berlin: Walter de Gruyter. pp 1-40. 